\title{
Effect of lipid-lowering therapy on the mortality among patients with coronary heart diseases: A systematic review
}

\author{
Abdullah Talal Almaghrabi ${ }^{(1)}$, Waleed Mohammed Alghamdi (1), Salah Mohammed Almuyidi \\ (2), Hadil Hilal Abuzaid ${ }^{(3)}$ \\ (1) University of Debrecen, (2) Faculty of Medicine, Taif University, (3) Applied Science Private \\ University
}

\begin{abstract}
:
Introduction: Studies supported the use of lipid lowering therapy such as statin as a treatment of hypercholesterolemia for prevention of CHD. However, the use of lipid lowering therapy is not well established in clinical practice due to lack of robust evidence and contra-indications in patients with heart failure (HF). This review aimed at evaluating the evidence about preventive effect of lipid lowering therapy on the mortality caused by coronary heart diseases. Methods: A comprehensive electronic search was carried out using MEDLINE, EMBASE, Cochrane databases to identify articles which aimed at assessing the preventive effect of lipid lowering therapy for coronary heart diseases. The data were collected from included studies using data collection sheets using specific items such as mean patient age, type of coronary disease, mean duration of the disease, drugs of lipid lowering therapy, regime of lipid lowering therapy, duration of lipid lowering therapy, reduction in mortality rate, and associated side effects. Results: Following evaluation of the eligible articles, 11 articles were included with randomized controlled trials investigating the effect of lipid-lowering therapy on the mortality of patient suffering from coronary heart diseases. The sample size in the included studies ranged from 106 to 10355 participants, and the total number of participants among all included studies were 50830 with mean age ranging from 31 to 82 years old. Conclusions: Despite the overall good outcome that is attributed to the use of statins that is not clear weather this benefit is credited to its antiinflammatory or direct LDL lowering effect.
\end{abstract}

Keywords: Lipid, Therapy, Statin, Heart failure, Myocardial infarction

Introduction:

Coronary heart disease (CHD) has been considered as a major factor that contributes to morbidity and debility, particularly among middle aged men ${ }^{(1)}$. Thus, the cardiologist and public health specialists have directed their efforts toward diagnostic and therapeutic methods with continuous updating of the guidelines (2). Recently, the preventive interventions have been found to be more costeffective than curative approach in reduction of morbidity and mortality associated with CHD (3).

The corner stone of preventive approach is targeting modifiable risk factors of CHD such as hyperlipidemia, hypertension and smoking (4). Guidelines for management of hypertension and hyperlipidemia were postulated to provide basis for CHD prevention ${ }^{(5)}$. Hyperlipidemia is a significant risk factor that is characterized by elevated low-density lipoprotein or triglyceride and occasionally low level of high-density lipoprotein ${ }^{(\boldsymbol{\sigma}}$. Studies supported the use of lipid lowering therapy such as statin as a treatment of hypercholesterolemia for prevention for CHD (7). However, the use of lipid lowering therapy is not well established in clinical practice due to lack of robust evidence and contra-indications in patients with heart failure (HF) ${ }^{(7,8)}$.

This review aimed at evaluating the evidence about preventive effect of lipid lowering therapy on the mortality caused by coronary heart diseases.

Methods:

A comprehensive electronic search was conducted in MEDLINE, EMBASE, Cochrane databases to identify articles which aimed to assess the preventive effect of lipid lowering therapy in CHD. Search terms included ("coronary artery diseases" OR "heart disease" OR "ischemic heart disease") AND ("lipidlowering therapy" OR "cholesterol-lowering therapy" OR ezetimibe OR statin OR pitavastatin OR pravastatin OR anacetrapib) AND (mortality OR death). The titles and abstracts of the resultant articles were read by two independent reviewers to identify relevant articles as a primary screening step and to exclude irrelevant, duplicated or review articles. The full texts of these relevant articles were retrieved and the in-depth reading was conducted to exclude the irrelevant articles as a secondary screening step. The articles were assessed against inclusion criteria such as 
clinical trials, published in the last 10 years and written in English language. The population studied should be patients with CHD, while included intervention was lipid lowering therapy. The outcomes assessed were the mortality indicators in rates or percentages. The data were collected from included studies using data collection sheets regarding item such as mean patient age, type of coronary disease, mean duration of the disease, drugs of lipid lowering therapy, regime of lipid lowering therapy, duration of lipid lowering therapy, reduction in mortality, and associated side effects. The review was registered in a registration of systematic review in university of York.

\section{Results:}

The electronic searches resulted in a total of 99 articles, of them 67 articles were excluded at the primary screening phase due to irrelevant aims or duplicated publishing. Furthermore, after retrieving of full texts, 21 articles were excluded because of insufficient information, different targeted populations, inconsistent methods or outcomes, or review studies. Finally, 11 articles were included which were randomized controlled trials dealing with the effect of lipid-lowering therapy on the mortality of coronary heart $(\mathrm{CH})$ problems among patients with CHD (Fig. 1). The sample size in the included studies ranged from 106 to 10355 participants, and the total number of participants among all included studied were 50830 with mean age ranging from 31 to 82 years old (Table 1). Regarding the side effects of the lipid lowering agents that have been mentioned in this review, a study found one case of AST and ALT elevation and one case of myalgia in the Rosuvastatin group, also two cases of AST and ALT elevation and one case of myalgia in Ezetimibe group. Beside myalgia, another study showed gastrointestinal discomfort, allergic reactions, psychoneurological symptoms, erectile dysfunction, and edema as adverse effects of Xuezhikang. Studies mentioned liver enzymes abnormalities and myalgia as Atorvastatin side effects. Allergic reaction, myalgia and neurological symptoms have been the unwanted effects of Alirocumab and did not mention any un desirable effects foe their drugs. Many studies focused on myocardial infarction (MI), unstable angina was the diseases that the participants. Other studies targeted population with hypertension (HTN) either alone or accompanied by another CHD. Also, patients with coronary atherosclerotic heart disease have studies by included studies. A verity of medications has been mentioned throughout the studies, Pravastatin, Xuezhikang, Atorvastatin, Alirocumab. Some included studies compared between Ezetimibe and Rosuvastatin or Atorvastatin versus simvastatin. The duration of theses lipid lowering agents use has been ranged from 1- 8 years (Table 1). The reduction in the mortality rate was calculated by different methods, and the majority of the studies revealed that there was no significant difference between the cases and the control groups. Xuezhikang was found to decrease significantly the risk of CHD death by $29.2 \%$ and one included study reported no death. Death from coronary heart disease due to Alirocumab use is less than in placebo user group (4 Alirocumab, 7 placebo). Two studies have used markers to determine the drugs effect.

\section{Figure (1): Flow diagram of the included studies in the systematic review}

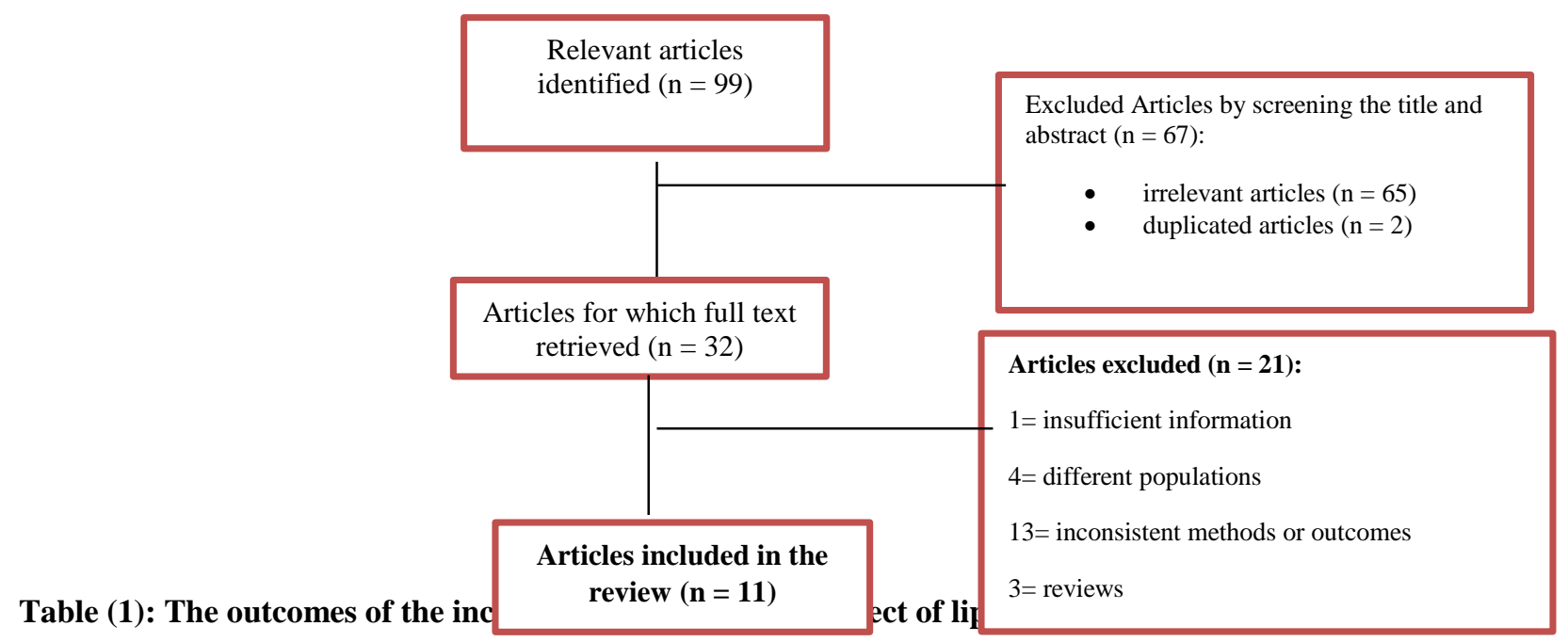


Effect of lipid-lowering therapy on the mortality among patients with coronary heart diseases...

\begin{tabular}{|c|c|c|c|c|c|c|c|c|c|}
\hline Study & $\begin{array}{l}\text { Sample } \\
\text { size }\end{array}$ & Patient age & $\begin{array}{l}\text { Type of } \\
\text { coronary } \\
\text { disease }\end{array}$ & $\begin{array}{c}\text { Mean } \\
\text { duration } \\
\text { of the } \\
\text { disease }\end{array}$ & $\begin{array}{l}\text { Drugs of } \\
\text { lipid } \\
\text { lowering } \\
\text { therapy }\end{array}$ & $\begin{array}{c}\text { Regime of lipid } \\
\text { lowering } \\
\text { therapy }\end{array}$ & $\begin{array}{c}\text { duration of } \\
\text { lipid } \\
\text { lowering } \\
\text { therapy }\end{array}$ & $\begin{array}{l}\text { Reduction in } \\
\text { mortality }\end{array}$ & Side effects \\
\hline (9) & $\begin{array}{c}106 \text { male } \\
\text { patients }\end{array}$ & $\begin{array}{c}63 \pm 10 \text { in } \\
\text { Ezetimibe } \\
\text { group } \\
\\
65 \pm 12 \text { in } \\
\text { Rosuvastati } \\
n\end{array}$ & $\begin{array}{l}\text { Coronary } \\
\text { atherosclerot } \\
\text { ic heart } \\
\text { disease }\end{array}$ & $\begin{array}{l}\text { Not } \\
\text { reported }\end{array}$ & $\begin{array}{l}\text { Ezetimibe } \\
\quad(\mathrm{n}=55) \\
\\
\text { Rosuvastati } \\
\mathrm{n} \text { alone } \\
(\mathrm{n}=51)\end{array}$ & $\begin{array}{c}\text { Ezetimibe } \\
\text { (10mg, once a } \\
\text { night) plus } \\
\text { rosuvastatin } \\
\text { (10mg, once a } \\
\text { night) } \\
\text { Rosuvastatin } \\
\text { alone (10mg, } \\
\text { once a night) }\end{array}$ & 12 months & $\begin{array}{l}\text { The cardiac } \\
\text { death was } 0 \text { in } \\
\text { both groups }\end{array}$ & $\begin{array}{c}1 \text { case of } \\
\text { AST or ALT }> \\
3 \times \text { ULN } \\
1 \text { case of } \\
\text { myalgia } \\
2 \text { cases of } \\
\text { AST or ALT }> \\
3 \times \text { ULN } \\
1 \text { case of } \\
\text { myalgia }\end{array}$ \\
\hline (10) & $\begin{array}{c}9014 \\
\text { patients }\end{array}$ & $\begin{array}{c}31 \text { to } 75 \\
\text { years }(7498 \\
\text { men, } 1516 \\
\text { women) }\end{array}$ & $\begin{array}{c}\text { MI/ } \\
\text { unstable } \\
\text { angina }\end{array}$ & $\begin{array}{c}\text { 3-36 } \\
\text { months } \\
\text { previously }\end{array}$ & Pravastatin & $40 \mathrm{mg}$ & 1 year & $\begin{array}{l}\text { Lp-PLA2 } \\
\text { activity levels } \\
\text { were reduced } \\
\text { by } 16 \% \text { in the } \\
\text { pravastatin } \\
\text { group } \\
\end{array}$ & Not reported \\
\hline (11) & 1530 & $\begin{array}{l}>\text { or }=65- \\
\text { years-old }\end{array}$ & $\begin{array}{c}\text { HTN } \\
+ \\
\text { Previous MI }\end{array}$ & $\begin{array}{l}\text { Had } 28 \\
\text { MI days } \\
\text { and } 5 \\
\text { years } \\
\text { before } \\
\text { entering } \\
\text { the study }\end{array}$ & $\begin{array}{l}\text { Xuezhikang } \\
(\mathrm{n}=772) \\
\text { partial } \\
\text { extract of } \\
\text { red yeast } \\
\text { rice } \\
\text { containing } \\
\text { statin } \\
\text { placebo (n } \\
=758)\end{array}$ & $\begin{array}{l}0.6 \mathrm{~g} \text { twice } \\
\text { daily }\end{array}$ & $\begin{array}{c}\text { Average of } \\
4.5 \text { years }\end{array}$ & $\begin{array}{c}\text { Xuezhikang } \\
\text { significantly } \\
\text { decreased the } \\
\text { risk of CHD } \\
\text { death by } \\
29.2 \% \text {. }\end{array}$ & $\begin{array}{l}\text { Gastrointestinal } \\
\text { discomfort, } \\
\text { allergic } \\
\text { reactions } \\
\text { myalgia, } \\
\text { psychoneurolog } \\
\text { ical symptoms, } \\
\text { erectile } \\
\text { Dysfunction, } \\
\text { and edema. }\end{array}$ \\
\hline (12) & $\begin{array}{c}2442 \\
\text { patients }\end{array}$ & $\begin{array}{l}\text { Comparing } \\
\text { between } 65- \\
78 \text { years old } \\
\text { patients and } \\
<65 \text { years } \\
\quad \text { old }\end{array}$ & $\begin{array}{l}\text { Myocardial } \\
\text { infarction } \\
\text { Unstable } \\
\text { angina } \\
\text { Congestive } \\
\text { heart failure }\end{array}$ & $\begin{array}{l}\text { Not } \\
\text { reported }\end{array}$ & $\begin{array}{c}\text { Atorvastati } \\
\mathrm{n}\end{array}$ & $\begin{array}{l}10 \mathrm{mg} / \mathrm{d} \text { up to } \\
\text { the maximum } \\
\text { dose } 80 \mathrm{mg} / \mathrm{d}\end{array}$ & $\begin{array}{c}53.9 \\
\text { months }\end{array}$ & $\begin{array}{l}\text { Reduction in } \\
\text { cardiac death } \\
+ \text { nonfatal MI } \\
\text { in } \\
\text { Atorvastatin } \\
\quad \text { group }\end{array}$ & $\begin{array}{l}\text { Elevations (>3 } \\
\text { times the upper } \\
\text { limit of normal) } \\
\text { of aspartate } \\
\text { aminotransferas } \\
\text { e levels alanine } \\
\text { aminotransferas } \\
\text { e levels both of } \\
\text { them is greater } \\
\text { in the older } \\
\text { group }\end{array}$ \\
\hline (9) & 1902 & $\begin{array}{c}\text { Women } \\
\text { mean age } \\
(63.5) \\
\text { Men mean } \\
\text { age }(60.4)\end{array}$ & $\begin{array}{l}\text { Myocardial } \\
\text { infarction } \\
\text { (MI } \\
\text { previous or } \\
\text { present } \\
\text { angina } \\
\end{array}$ & $\begin{array}{l}\text { Not } \\
\text { reported }\end{array}$ & $\begin{array}{c}\text { Atorvastati } \\
\mathrm{n}\end{array}$ & $\begin{array}{l}10 \mathrm{mg} / \text { day } \\
80 \mathrm{mg} / \text { day } \\
\text { (intensive) }\end{array}$ & 4.9 years. & $\begin{array}{l}\text { Non- } \\
\text { significant } \\
\text { reduction in } \\
\text { CHD deaths }\end{array}$ & $\begin{array}{l}\text { Myalgia } \\
\text { Liver function } \\
\text { test up } \\
\text { normality }\end{array}$ \\
\hline (13) & $\begin{array}{c}2867 \\
1467 \text { parti } \\
\text { cipants } \\
\text { on prava } \\
\text { And } \\
1400 \\
\text { participa } \\
\text { nts on } \\
\text { usual } \\
\text { care }\end{array}$ & $\begin{array}{c}65 \text { to } 74 \\
\text { years and } \\
\geq 75 \text { years }\end{array}$ & $\begin{array}{l}\text { HTN with at } \\
\text { least one } \\
\text { CHD }\end{array}$ & $\begin{array}{l}\text { Not } \\
\text { reported }\end{array}$ & $\begin{array}{l}\text { Pravastatin } \\
\text { sodium } \\
\text { Vs } \\
\text { Usual care } \\
\text { (UC) }\end{array}$ & $40 \mathrm{mg} / \mathrm{d}$ & 6 years & $\begin{array}{c}\text { Non- } \\
\text { significant } \\
\text { difference } \\
\text { CHD death }\end{array}$ & Not reported \\
\hline (14) & $\begin{array}{c}2341 \\
\text { patients }\end{array}$ & $\begin{array}{l}\text { The mean } \\
\text { age } 60 \text { years }\end{array}$ & $\begin{array}{c}68.9 \% \\
\text { of the } \\
\text { patients had } \\
\text { a history of } \\
\text { coronary } \\
\text { heart } \\
\text { disease (all } \\
\text { Patients are } \\
\text { already on } \\
\text { statin } \\
\text { therapy ) }\end{array}$ & $\begin{array}{l}\text { Not } \\
\text { reported }\end{array}$ & $\begin{array}{c}\text { Alirocumab } \\
\text { or } \\
\text { placebo }\end{array}$ & $\begin{array}{c}\text { Alirocumab } \\
(150 \mathrm{mg}) \text { or } \\
\text { placebo as a } 1- \\
\mathrm{ml} \\
\text { subcutaneous } \\
\text { injection every } \\
2 \text { weeks }\end{array}$ & $\begin{array}{l}\text { for } 78 \\
\text { weeks }\end{array}$ & $\begin{array}{l}\text { Death from } \\
\text { coronary heart } \\
\text { disease, } \\
\text { including } \\
\text { death from } \\
\text { unknown } \\
\text { cause } \\
4 \text { patients } \\
\text { And } \\
7 \text { in placebo } \\
\text { group }\end{array}$ & $\begin{array}{c}\text { General allergic } \\
\text { reaction } \\
\text { Myalgia } \\
\text { Neurologic } \\
\text { event }\end{array}$ \\
\hline (15) & $\begin{array}{l}, 522 \\
1,765 \\
\text { males }\end{array}$ & $\begin{array}{c}\text { Patients } \\
\text { aged 70-82 }\end{array}$ & $\begin{array}{l}\text { History of or } \\
\text { risk factors } \\
\text { for CVD }\end{array}$ & $\begin{array}{l}\text { Not } \\
\text { reported }\end{array}$ & $\begin{array}{l}\text { Pravastatin } \\
\text { Versus } \\
\text { Placebo }\end{array}$ & (40 mg) & 3.2 years. & $\begin{array}{c}\text { No significant } \\
\text { difference in } \\
\text { CHD } \\
\text { mortality }\end{array}$ & Not reported \\
\hline
\end{tabular}




\begin{tabular}{|c|c|c|c|c|c|c|c|c|c|}
\hline & $\begin{array}{c}1757 \\
\text { females }\end{array}$ & & & & & & & & \\
\hline (16) & $\begin{array}{c}7,863 \\
\text { patients }\end{array}$ & $31-75$ years & $\begin{array}{c}\text { MI } \\
\text { or } \\
\text { Unstable } \\
\text { angina }\end{array}$ & $\begin{array}{l}\text { Not } \\
\text { reported }\end{array}$ & $\begin{array}{c}\text { Pravastatin } \\
\text { or } \\
\text { Placebo }\end{array}$ & $40 \mathrm{mg}$ per day & 6 years & $\begin{array}{c}\text { Higher } \\
\text { baseline TnI } \\
\text { levels were } \\
\text { associated } \\
\text { with a larger } \\
\text { absolute } \\
\text { benefit of } \\
\text { pravastatin } \\
\text { and therefore } \\
\text { fewer } \\
\text { numbers } \\
\text { needed to } \\
\text { treat. }\end{array}$ & Not reported \\
\hline (17) & $\begin{array}{c}10,355 \\
\text { participa } \\
\text { nts }\end{array}$ & $\geq 55$ years & HTN & $\begin{array}{l}\text { Not } \\
\text { reported }\end{array}$ & $\begin{array}{c}\text { Pravastatin } \\
(\mathrm{n}=5170) \\
\text { or } \\
\text { usual care } \\
(\mathrm{n}=5185)\end{array}$ & $(40 \mathrm{mg} / \mathrm{d})$ & 4 to 8 years & $\begin{array}{c}\text { No significant } \\
\text { differences } \\
\text { between } \\
\text { groups }\end{array}$ & Not reported \\
\hline (18) & $\begin{array}{c}8,888 \\
\text { participa } \\
\text { nts }\end{array}$ & $\begin{array}{l}\geq 65 \text { years } \\
\text { versus } \\
<65 \text { years }\end{array}$ & $\begin{array}{l}\text { Myocardial } \\
\text { infarction }\end{array}$ & $\begin{array}{l}\text { Not } \\
\text { reported }\end{array}$ & $\begin{array}{l}\text { Atorvastati } \\
\mathrm{n} \text { versus } \\
\text { Simvastatin }\end{array}$ & $\begin{array}{c}\text { (80 mg/day) } \\
\text { (20 to } 40 \\
\text { mg/day) }\end{array}$ & 1 year & $\begin{array}{l}\text { No significant } \\
\text { difference } \\
\text { regarding } \\
\text { cardiovascular } \\
\text { death }\end{array}$ & $\begin{array}{c}\text { Muscle and } \\
\text { liver } \\
\text { abnormalities } \\
\text { Myopathy } \\
\text { Rhabdomyolysi } \\
\text { s }\end{array}$ \\
\hline
\end{tabular}

\section{Discussion:}

A review of eleven randomized controlled trials (RCTs) studies, included a wide range of patients from (106-10355) were involved in the present study. This large population size is considered a positive factor and a point of strength in this review ${ }^{(13)}$.The participants were of old age (31-82) aiming at observing the effect of lipid-lowering therapy on the mortality of coronary heart $(\mathrm{CH})$ problems among patients with CHD and other comorbidities. Procedures and guidelines have been directed toward prevention of the consequences of chronic heart disease (2), one of these prophylaxis measurements is the lipid lowering agents (statin and others) which were founded to be of great value in decreasing the mortality rate in patients of old age (1). LDL and cholesterol levels should be in their minimum range. Resulting in that most of the lipid lowering agents were not significant in reducing the mortality rate. That may be partially attributed to that most of the control groups were using (usual care) which is consisting of a lipid lowering drug plus major adjustment that were done to improve the daily life style ${ }^{(19)}$.

The follow up period needed to be longer for better effects observation, this will also help in detecting new side effects and give a time for informative testing of these adverse effects ${ }^{(19)}$. The studies with significant results containing statins as the drug of choice with fair effect, for that statins holds the record of being the best agents in lowering the LDL levels (20). Furthermore, statins had a side effect profile that is tolerable for most patients but not that much for high risk old patients as studies documented that it's effect with muscle ache and lack of proper muscle function. In addition, few cognitive side effects accompanying their use that is why more attention is needed to be addressed regarding this issue ${ }^{(21)}$. Fortunately, studies demonstrated that using statins with a significantly high dose (aggressive treatment) in old patient affect the result of LDL level thus enhancing the overall health status ${ }^{(22)}$ of the patient especially those ailments that are related to the cardiovascular events ${ }^{(13,23)}$.

\section{Conclusions:}

This review concluded that, there was no clear results regarding effect of statins, and other lipid lowering medications, in reduction of the mortality rate that is caused by cardiovascular events. Despite the overall good outcome due to the use of statins, it was not clear weather this 
Effect of lipid-lowering therapy on the mortality among patients with coronary heart diseases...

benefit is credited to its anti inflammatory or direct LDL lowering effect.

References:

1.Drewes YM, Poortvliet RK, Blom JW, Ruijter W, Westendorp RG, Stott DJ et al. (2014): Homocysteine levels and treatment effect in the PROspective Study of Pravastatin in the Elderly at Risk. J Am Geriatr Soc., 62(2):213221.

2.Shepherd J, Cobbe SM, Ford I, Isles CG, Lorimer AR, Macfarlane PW et al. (1995): Prevention of coronary heart disease with pravastatin in men with hypercholesterolemia. N Engl J Med., 333(20):1301-1308.

3.Unal B, Critchley JA, Capewell S (2005): Modelling the decline in coronary heart disease deaths in England and Wales, 1981-2000: comparing contributions from primary prevention and secondary prevention. Bmj., 331(7517):614.

4.Koren MJ, Feldman T, Mendes RA (2009): Impact of High-Dose Atorvastatin in Coronary Heart Disease Patients Age 65 to 78 Years. Clin Cardiol., 32(5):256-263.

5.Pyörälä K, De Backer G, Graham I, PooleWilson P, Wood D (1994): Prevention of coronary heart disease in clinical practice: recommendations of the Task Force of the European Society of Cardiology, European Atherosclerosis Society and European Society of Hypertension. Atherosclerosis, 110(2):121-161.

6.Navar-Boggan AM, Peterson ED, D'Agostino RB, Neely B, Sniderman AD, Pencina MJ (2015): Hyperlipidemia in Early Adulthood Increases Long-Term Risk of Coronary Heart DiseaseCLINICAL PERSPECTIVE. Circulation, 131(5):451-458.

7.Ward S, Jones ML, Pandor A, Holmes M, Ara R, Ryan A et al. (2007): A systematic review and economic evaluation of statins for the prevention of coronary events. HTA., 11(14): 1184

8.Cleland JG, McMurray JJ, Kjekshus J, Cornel JH, Dunselman P, Fonseca C et al. (2009): Plasma concentration of amino-terminal pro-brain natriuretic peptide in chronic heart failure: prediction of cardiovascular events and interaction with the effects of rosuvastatin: a report from CORONA (Controlled Rosuvastatin Multinational Trial in Heart Failure). J Am Coll Cardiol., 54(20):1850-1859.

9.Wang X, Zhao X, Li L, Yao H, Jiang Y, Zhang J (2016): Effects of combination of ezetimibe and rosuvastatin on coronary artery plaque in patients with coronary heart disease. Heart Lung Circ., 25(5):459-465.

10.White HD, Simes J, Stewart RA, Blankenberg S, Barnes EH, Marschner IC et al. (2013): Changes in lipoprotein-associated phospholipase A2 activity predict coronary events and partly account for the treatment effect of pravastatin: results from the Long-Term Intervention with Pravastatin in Ischemic Disease study. J Am Heart Assoc., 2(5):e000360.

11.Li JJ, Lu ZL, Kou WR, Chen Z, Wu YF, Yu XH et al. (2009): Beneficial impact of Xuezhikang on cardiovascular events and mortality in elderly hypertensive patients with previous myocardial infarction from the China Coronary Secondary Prevention Study (CCSPS). J Clin Pharmacol., 49(8):947-956.

12.Koren MJ, Feldman T, Mendes RA (2009): Impact of High-Dose Atorvastatin in Coronary Heart Disease Patients Age 65 to 78 Years. Clinical Cardiology. J Am Heart Assoc., 32(5):256-263.

13.Han BH, Sutin D, Williamson JD, Davis BR, Piller LB, Pervin H et al. (2017): Effect of statin treatment vs usual care on primary cardiovascular prevention among older adults: the ALLHAT-LLT randomized clinical trial. JAMA internal medicine, 177(7):955-965.

14.Robinson JG, Farnier M, Krempf M, Bergeron J, Luc G, Averna $M$ et al. (2015): Efficacy and safety of alirocumab in reducing lipids and cardiovascular events. N Engl J Med., 372(16):1489-1499.

15.Drewes YM, Poortvliet RK, Blom JW, de Ruijter W, Westendorp RG, Stott DJ et al. (2014): Homocysteine levels and 
treatment effect in the PROspective Study of Pravastatin in the Elderly at Risk. J Am Geriatr Soc., 62(2):213221.

16. White HD, Tonkin A, Simes J, Stewart R, Mann K, Thompson P et al. (2014): Association of contemporary sensitive troponin I levels at baseline and change at 1 year with long-term coronary events following myocardial infarction or unstable angina: results from the LIPID Study (Long-Term Intervention With Pravastatin in Ischaemic Disease). J Am Coll Cardiol., 63(4):345-354.

17.Margolis KL, Davis BR, Baimbridge C, Ciocon JO, Cuyjet AB, Dart RA et al. (2013): Long-Term Follow-Up of Moderately Hypercholesterolemic Hypertensive Patients Following Randomization to Pravastatin vs Usual Care: The Antihypertensive and LipidLowering Treatment to Prevent Heart Attack Trial (ALLHAT-LLT). J Clin Hypertens., 15(8):542-554.

18. Tikkanen MJ, Holme I, Cater NB, Szarek M, Faergeman O, Kastelein JJ et al. (2009): Comparison of efficacy and safety of atorvastatin $(80 \mathrm{mg})$ to simvastatin (20 to $40 \mathrm{mg}$ ) in patients aged $<65$ Versus $\geq 65$ years with coronary heart disease (from the incremental decrease through aggressive lipid lowering [IDEAL] study). Am J Cardiol., 103(5):577-582.

19.Athyros VG, Kakafika AI, Papageorgiou AA, Paraskevas KI, Tziomalos K,
Anagnostis P et al. (2008): Effects of statin treatment in men and women with stable coronary heart disease: a subgroup analysis of the GREACE Study. Curr Med Res Opin., 24(6):1593-1599.

20.Collins R, Reith C, Emberson J, Armitage $\mathrm{J}$, Baigent C, Blackwell $\mathrm{L}$ et al. (2016): Interpretation of the evidence for the efficacy and safety of statin therapy. The Lancet, 388(10059):25322561.

21.Sewright KA, Clarkson PM, Thompson PD (2007): Statin myopathy: incidence, risk factors, and pathophysiology. Curr Atheroscler Rep., 9(5):389-396.

22.Sever PS, Dahlöf B, Poulter NR, Wedel H, Beevers G, Caulfield M et al. (2003): Prevention of coronary and stroke events with atorvastatin in hypertensive patients who have average or lower-than-average cholesterol concentrations, in the Anglo-Scandinavian Cardiac Outcomes Trial-Lipid Lowering Arm (ASCOT-LLA): a multicentre randomised controlled trial. The Lancet, 361(9364):1149-1158.

23.Grundy SM, Cleeman JI, Merz CNB, Brewer HB, Clark LT, Hunninghake DB et al. (2004): Implications of recent clinical trials for the national cholesterol education program adult treatment panel III guidelines. Circulation, 110(2):227-239. 